DOI: $10.2478 / \mathrm{v} 10014-011-0011-\mathrm{y}$

Agrovoc descriptors: pisum sativum, transgenic plants, genotypes, peas, fungal diseases, plant diseases, ascochyta, rubus idaeus, resistance to injurious factors, agrobacterium, PCR

Agris category code: $\mathrm{H} 20$, F30

\title{
PCR identification of rpgip1 transgene in Pisum sativum L.
}

\author{
Kornelia POLOK ${ }^{1}$ and Hans-Jörg JACOBSEN ${ }^{2}$
}

Received July 30, 2011; accepted September 14, 2011.

Delo je prispelo 30. julija 2011, sprejeto 14. septembra 2011.

\begin{abstract}
Recent efforts to increase Ascochyta blight resistance of pea have focused on the introduction of foreign genes by genetic engineering. The rpgip1 gene from Rubus idaeus was introduced by Agrobacterium-mediated transformation into Pisum sativum, cv. Baroness with the aim to increase pea resistance to fungal diseases. Notwithstanding this success, practical applications have to be preceded by the development of analytical methods for screening. Singleplex and multiplex PCR assays were employed to test primer efficiency in identifying the rpgip1 transgene in 11 pea genotypes. Five from ten primer combinations were effective in identifying transgene or insert sequences. PCR amplification using five other primer pairs revealed unspecific amplicons. According to in silico analyses, they arose from retrotransposons and pea genes including homologues of rpgip1. Two sets of primers were prepared with the aim of simultaneous amplification of different rpgip1 fragments. Fingerprints were sums of bands observed from individual pairs so the utility of multiplex assays was demonstrated. An additional advantage of multiplex PCR was clear differentiation between the transgene and endogenous pgip genes present in the donor species, $R$. idaeus. Sequencing of two PCR products confirms that no substantial rearrangements at the rpgip1 transgene arose during development of transgenic plants. However, a deletion occurred at $59 \mathrm{bp}$ in the PGIP+VST line and a substitution at $392 \mathrm{bp}$ in the PGIP line. The frequency of point mutations was not high $\left(1.1 \times 10^{-3}\right)$ and comparable with the frequency expected for host genes based on the neutral theory of molecular evolution.
\end{abstract}

Key words: Transgenic pea, fungal diseases, Rubus idaeus, pgip homologues, multiplex PCR

\section{IZVLEČEK}

\section{PCR IDENTIFIKACIJA TRANSGENA rpgip1 PRI GRAHU (Pisum sativum L.)}

Novejši dosežki pri povečanju odpornosti graha na Ascochyta so povezani $\mathrm{z}$ uvajanjem tujih genov s pomočjo genskega inženiringa. Gen rpgip1 iz malinjaka (Rubus idaeus) je vključen v grah, cv. Baroness, s transformacijo z bakterijo Agrobacterium, da bi se povečalo odpornost graha na to glivično bolezen. Pred praktično uporabo te metode je potrebno razviti načine za spremljanje dedovanja tega transgena. Enojna in multipleks PCR sta bili uporabljeni za testiranje učinkovitosti začetnikov in za identificiranje transgena rpgip1 pri 11 genotipih graha. Pet od desetih začetnikov je bilo uporabnih za identifikacijo transgenov ali za vključevanje sekvenc. PCR namnoževanje z drugimi petimi začetniki je dalo nespecifične namnožke. Glede na in silico analize so ti nastali zaradi retrotranspozonov in grahovih genov, ki vključujejo homologe rpgip1. Dva seta začetnikov sta bila pripravljena za istočasno namnoževanje različnih odlomkov rpgip1. Elektroferogrami so bili vsote črt individualnih parov, tako je prikazana uporabnost multipleksnega poskusa. Dodatna prednost multipleksnega PCR je razločna diferenciacija med transgenom in genom pgip prisotnim v donorski vrsti $R$. idaeus. Sekvenciranje dveh PCR produktov potrjuje, da ni pri rpgip1 bistvenega prerazporejanja tekom razvoja transgenih rastlin. Toda pojavila se je delecija pri 59 bp $\mathrm{v}$ liniji PGIP+VST in substitucija pri 392 bp v liniji PGIP. Relativna pogostnost točkovnih mutacij ni bila visoka $\left(1.1 \times 10^{-3}\right)$ in je bila primerljiva $\mathrm{z}$ pogostnostjo pri gostiteljivih genih, glede na nevtralno teorijo molekulske evolucije.

Ključne besede: Transgeni grah, glivične bolezni, Rubus idaeus, homologi pgip, multipleksna PCR

\footnotetext{
1 Department of Genetics, University of Warmia and Mazury in Olsztyn, Plac Lodzki 3, 10-967 Olsztyn, Poland, kpolok@moskit.uwm.edu.pl

2 Plant Biotech Unit, Gottfried Wilhelm Leibniz Universität Hannover, Herrenhauserstr 2, D30-419 Hannover, Germany
} 


\section{INTRODUCTION}

The pea (Pisum sativum L.) has been grown since the prehistoric ages providing forage (field peas), fresh vegetable (market peas) and the material for canning and freezing (vining peas). With approximately $26 \%$ $33 \%$ proteins and a lower level of protein inhibitors than in soybean, peas are excellent protein supplements in human and animal diets (Cousin, 1997). Producing nearly two million tons of peas per year, Europe has recently provided one-fifth of world production. However, the yield is unstable with the average yield per hectare ranging from 1.3 tons to 4.8 tons (Eurostat, 2011). Consequently, many characters have to be improved and Ascochyta blight is the major factor limiting pea production up to $75 \%$ (McDonald and Peck, 2009). Symptoms include dark-brown lesions or flecks on all plant parts, seedling blight and foot rot. The disease is caused by related fungal pathogens of the Ascochyta complex (Mycosphaerella pinodes, Ascochyta pisi, Phoma medicaginis).

Pea genotypes differ in susceptibilities to Ascochyta pathogens but complete resistance to infection has not been observed (Timmerman-Vaughan et al., 2002). On the other hand, disease resistance is often encoded by major plus minor genes. Numerous genomic regions responsible for partial resistance have been located on linkage groups II, III, IV, V and VII (TimmermanVaughan et al., 2002; Prioul-Gervais et al., 2007). Unfortunately, the biological function of the underlying factors still remains unknown. The quantitative inheritance, the lack of information on the molecular mechanism underlying resistance and genotypeenvironment interaction emphasized by variation in disease development with both growing areas and climate conditions make the traditional resistant breeding difficult. Therefore, recent efforts to increase Ascochyta blight resistance of pea, directly correlated with the yield and quality of seeds, have focused on the introduction of foreign genes by genetic engineering.

A classic tactic for producing transgenic plants with increased resistance is to introduce $R$ genes, products of which recognise pathogen Avr genes' determinants. When corresponding $R$ and Avr genes are present, the disease resistance is brought in the classic gene-to gene manner. Good examples of this system are plant pgip genes encoding polygalacturonase inhibiting proteins (PGIPs) and fungal $P G$ genes responsible for fungal endopolygalacturonases (PGs) - enzymes degrading polysaccharides of the cell wall. The PGIPs inhibit fungal endo-PGs, thus preventing the hydrolysis of the $\alpha-1,4$ glycosidic bonds (Shanmugam, 2005; Di Matteo et al., 2006). A range of crops including tomato (Powell et al., 2000), apple (Szankowski et al., 2003), and wheat (Janni et al., 2008) were transformed with pgip genes to improve plant defence against fungal pathogens. In a case of pea, the rpgip1 gene from red raspberry, Rubus idaeus (Accession $\mathrm{N}^{\circ} \mathrm{AJ} 620336$ ) was introduced by Agrobacterium-mediated transformation into cv. Baroness (Richter et al., 2006). Stable inheritance was confirmed and transgenic lines showed significant inhibitory effects on the polygalacturonases of Colletotrichum lupini and Stenocarpella maydis in a greenhouse experiment. Notwithstanding the usefulness of the transgenic approach to produce pea resistant to fungal diseases, practical applications have to be preceded by the development of analytical methods for screening. They are necessary to allow consumers a free choice between genetically modified (GM) and traditional crops. Controlling the structural integrity of the transgene during further manipulations is not less important. It is a norm that unexpected variation is found in transgenic lines during later experiments or commercial use. For instance, expression of rpgip1 varied greatly among both transgenic pea individuals and subsequent generations (Richter et al., 2006). Among many reasons for this phenomenon, rearrangements at a transgene locus are frequently mentioned (Morino et al., 1999; Svitashev et al., 2002).

Direct sequence analysis is the most reliable way to identify transgenes and study their structure. However, it is too time and cost consuming when a large number of samples have to be tested. For this reason, various types of polymerase chain reaction (PCR) are adopted to enable reliable and rapid assessments of GMOs. Eventspecific methods, which are preferred in EU, are based on a sequence unique to a certain GMO. Such assays have to be developed for each new GMO, so do for transgenic peas expressing antifungal genes (e.g., rpgip1). A critical point is that PCR should differentiate between a transgene and homologous, endogenous sequences. At least two pea sequences homologous to rpgip1 are deposited in the GenBank maintained by the National Centre for Biotechnology Information (NCBI). Both genes can be a putative template for unintended amplification driven by primers specific to rpgip1. One possibility to overcome the problem is to design a set of primers to track different gene fragments. A simpler but yet a reliable method to differentiate between a transgene and homologues can employ several primers at once in so called multiplex PCR.

In the present studies a set of primers was used to identify the rpgip1 transgene in different genotypes of $P$. sativum. The primer efficiency in differentiating between the transgene and pea homologues was assessed as well as sets for multiplex PCR were proposed. We tried to understand why some primers preferentially amplified pea homologues instead of the rpgip1 transgene. Results were discussed in the light of possible rearrangements of the transgene. 


\section{MATERIALS AND METHODS}

\subsection{Plant material}

Two transgenic lines: PGIP - a homozygous line carrying two copies of the rpgip1 gene from Rubus idaeus. PGIP+VST - a homozygous line with stacked antifungal genes, rpgip1 and Vst1 encoding stilbene synthase in Vitis vinifera. It was obtained by reciprocal crosses of the PGIP line expressing rpgip1 and a line expressing the Vst1 gene. Plants used in the analysis represented $\mathrm{F}_{8}$ and further generations (Richter et al., 2006). In total 15 plants per both lines were used in the analyses.

Six rpgip hemizygotes: $F_{1}$ hybrids derived from crosses between the PGIP or PGIP+VST lines and the parent cultivar Baroness (Bar x PGIP and Bar x PGIP+VST), the arthritic mutant from Paloma (arth $\mathrm{x}$ PGIP), the ramosus mutant from Parvus (PGIP x ram and PGIP+VST x ram) and the Polish cultivar Sokolik (PGIP+VST x Sok). All hybrids were expected to carry at least one copy of rpgip1.

Negative controls: Baroness - parent cultivar, from which transgenic lines were derived (15 plants in total); Bar x VST the $F_{1}$ between Baroness and the transgenic line with Vst1 gene; ram $\mathrm{x}$ Bar - the $\mathrm{F}_{1}$ between the ramosus mutant from Parvus and Baroness.

Positive controls: pSCP1 plasmid - a binary vector using for pea transformation and carrying a nos promoter-driven bar gene and a double $35 \mathrm{~S}$ promoter-driven the rpgip1 gene from $R$. idaeus (Richter et al., 2006). The rpgip1 transgene sequence consists of 996 base pairs (bp) and corresponds to the $29 \mathrm{bp}-1024$ bp of rpgip1 in the NCBI file, accession
$\mathrm{N}^{\mathrm{o}}$ AJ6200336. Moreover, a wild ecotype of red raspberry (R. idaeus) was used for comparisons between transgenic and donor species fingerprints.

\subsection{DNA isolation}

Plant genomic DNA was extracted from about $1 \mathrm{~g}$ of young leaves by the modified CTAB procedure (Polok, 2007). The quality of DNA was verified on $1 \%$ agarose gels while the purity was assessed spectrophotometrically and it ranged between $93 \%$ and $99 \%$. The DNA content of the samples ranged from $177 \mu \mathrm{g}$ to $568 \mu \mathrm{g}$. The DNA of pSCP1 plasmid was provided by the Plant Biotech Unit, Leibniz Universität Hannover.

\subsection{Primers}

Eight primers distributed over the entire transgene were designed on the rpgip1 sequence used in the pSCP1 transformation vector. Numbers in primers' abbreviations identify their 5'position on the rpgip1 template. Forward primers: 1F: 5'atgatggacttcaagctctt3'; 6F: 5'ggacttcaagctcttctccc3'; 108F: 5'caagacagcttcaacaaccc3'; 421F: 5'cagctcaagaacctcacatt3'. Reverse primers: 366R: 5' cttgagatgtttaagcttgg3'; 733R: 5'ccacaatctgggtggtcttgt3'; 958R: 5'ggttatggaaatacgacgtg3', 971R: 5' gcaacttgggaggggagcac3'. Ten pairwise combinations of forward and reverse primers and two multiplex sets with four and three primers were applied (Table 1).

Table 1. Primer combinations and PCR conditions.

\begin{tabular}{|c|c|c|c|c|}
\hline \multicolumn{2}{|c|}{ Primer combination } & \multirow{2}{*}{$\begin{array}{c}\begin{array}{c}\text { Annealing temperature } \\
{\left[{ }^{\circ} \mathbf{C}\right]}\end{array} \\
58\end{array}$} & \multirow{2}{*}{$\begin{array}{c}\begin{array}{c}\text { Number of cycles } \\
\text { [n] }\end{array} \\
30\end{array}$} & \multirow{2}{*}{$\begin{array}{c}\begin{array}{c}\text { Predicted product length } \\
\text { [bp] }\end{array} \\
366\end{array}$} \\
\hline \multirow{10}{*}{$\frac{0}{\frac{0}{2}}$} & $1 F-366 R$ & & & \\
\hline & $1 F-733 R$ & 58 & 30 & 733 \\
\hline & 1F-958R & 58 & 30 & 958 \\
\hline & $108 \mathrm{~F}-366 \mathrm{R}$ & $\begin{array}{l}\text { Touchdown: } \\
48-0.8 \text { then } 40\end{array}$ & $10+20$ & 259 \\
\hline & 108F-733R & 48 & 30 & 626 \\
\hline & $108 \mathrm{~F}-958 \mathrm{R}$ & 58 & 30 & 851 \\
\hline & $421 \mathrm{~F}-366 \mathrm{R}$ & 40 & 30 & $942 *$ \\
\hline & $421 \mathrm{~F}-733 \mathrm{R}$ & 50 & 30 & 313 \\
\hline & $421 \mathrm{~F}-958 \mathrm{R}$ & 58 & 35 & 538 \\
\hline & $6 \mathrm{~F}-971 \mathrm{R}$ & 41 & 35 & $958,1700^{*}$ \\
\hline \multirow{4}{*}{ 曾 } & Set 1: & & & \\
\hline & $\begin{array}{r}1 F-366 R+ \\
733 R+958 R\end{array}$ & 58 & 35 & $366,733,958$ \\
\hline & Set 2: & & & \\
\hline & $\begin{array}{r}108 \mathrm{~F}+421 \mathrm{~F}- \\
958 \mathrm{R}\end{array}$ & 58 & 35 & 538,851 \\
\hline
\end{tabular}

*Product predicted for the plasmid and only when circular matrix is assumed. 


\subsection{PCR conditions}

Singleplex PCR: PCR was performed in a $20 \mu \mathrm{l}$ volume containing $20 \mathrm{mM}\left(\mathrm{NH}_{4}\right)_{2} \mathrm{SO}_{4}, 50 \mathrm{mM}$ Tris-HCl, $\mathrm{pH} 9.0$ at $25^{\circ} \mathrm{C}, 1.5 \mathrm{mM} \mathrm{MgCl}, 2 \mu \mathrm{l}$ of Enhancer with betaine (Epicentre Technology), $200 \mu \mathrm{M}$ dNTPs, $1.0 \mu \mathrm{M}$ primers, $0.75 \mathrm{U}$ of $\mathrm{Tfl}$ polymerase (Epicentre Technology) and $80 \mathrm{ng}$ of template DNA. The standard thermal conditions were: $94^{\circ} \mathrm{C}$ for $3 \mathrm{~min}$, followed by 30 cycles of $94^{\circ} \mathrm{C}$ for $1 \mathrm{~min}, 58^{\circ} \mathrm{C}$ for 1 $\min , 72^{\circ} \mathrm{C}$ for $1 \mathrm{~min}$. The final extension was at $72^{\circ} \mathrm{C}$ for 5 min. However, conditions for five pairs were optimized and finally a number of cycles were increased in two cases while annealing temperature was modified in three ones (Table 1). PCR products were loaded on $1.5 \%(\mathrm{w} / \mathrm{v})$ agarose gels containing $0.5 \mu \mathrm{g} / \mathrm{ml}$ ethidium bromide, separated in $1 \mathrm{x}$ TBE buffer (Tris-Borate-EDTA) at $100 \mathrm{~V}$ constant power, visualized under UV light $(312 \mathrm{~nm})$, photographed with Olympus Camera and stored as .jpg files. Multiplex PCR: The same reagent concentrations and standard thermal conditions were applied as for singleplex PCR with the exception of a number of cycles that was increased to 35 .

\subsection{Sequencing}

PCR products revealed by primers $1 \mathrm{~F}-733 \mathrm{R}$ and $1 \mathrm{~F}-958 \mathrm{R}$ in transgenic plants and the pSCP1 plasmid were sequenced. The PCR products were separated on $1.5 \%$ agarose gels, excised and purified using the gel-out system (AKOR Laboratories). The identities of the products were confirmed by nested PCR and restriction analyses. Sequencing was performed using the ABI3730 and BigDye Terminator Ready Cycle Sequencing Kit (Applied Biosystem) with the 1F primer by oligo.pl, Institute of Biochemistry and Biophisics PAS.

\subsection{In silico and sequence analyses}

The specificity of primers was tested by Primer-BLAST against Pisum sequences deposited in the non-redundant database at NCBI. Possibilities of unintended amplification were studied by performing in silico PCR on the rpgip1 template and two pea homologues deposited at NCBI (AB0877839, AJ749705) using FastPCR software. Multiple alignment algorithms in CLUSTALX2 were applied for sequence comparisons. Sequences were viewed in Jalview 2.6.1 editor.

\section{RESULTS}

\subsection{Amplification of the rpgip1 transgene on the pSCP1 template}

The majority of primer pairs amplified a product of a size corresponding to rpgip1 while using the pSCP1 template (Fig. 1, 2). Thus, their usefulness in identification of the transgene was confirmed. Interestingly, only five pairs amplified a single, expected band (1F-366R, 1F-958R, 108F-366R, 108F733R, 421F-733R), while the other five revealed two bands (1F-733R, 108F-958R, 421F-366R, 421F-958R and $6 \mathrm{~F}-971 \mathrm{R})$. The first of two products fell within the expected size range but the second was much shorter and faint. Surprisingly, primers $421 \mathrm{~F}$ and $366 \mathrm{R}$ resulted in two, clearly visible but relatively short amplicons (350 bp, $490 \mathrm{bp}$ ) although the target sites' orientation rather excluded amplification (Table 1). In silico PCR used for quick primer analyzing on the rpgip1 template demonstrated that some of additional, shorter products could result from unspecific amplification of the transgene. Likely, this explanation is valid for the 420 bp product revealed by 108F-958R but not for the other pairs of primers, for which even very weak searching criteria (7 mismatches, initial word size of 2) did not result in virtual, unspecific amplification. Therefore, it was assumed, that additional bands were probably derived from unintended amplification of other plasmid sequences. Pairs of primers amplifying additional plasmid sequences included 1F-733R (480 bp), 421F958R (300 bp), 421F-366R (350 bp and $490 \mathrm{bp}$ ), and 6F-971R (740 bp).

\subsection{Efficiency of primer combinations in identification of the rpgip1 transgene in P. sativum}

Amplification patterns of the pSCP1 vector demonstrated that all primer pairs could theoretically detect the transgene and eventually other sequences within an insert. Surprisingly, among ten pairs of primers checked, only $50 \%$ of combinations gave the plasmid banding pattern in transgenic PGIP and PGIP+VST plants and no amplification in the parent cultivar, Baroness (Fig. 1). This first group included 1F366R, 1F-733R，1F-958R，421F-733R，421F-958R pairs. They can further be used in identifying the transgene in various backgrounds as confirmed by fingerprints of rpgip1 hemizygotes similar to these of transgenic lines and no amplification in negative controls (Table 2). 


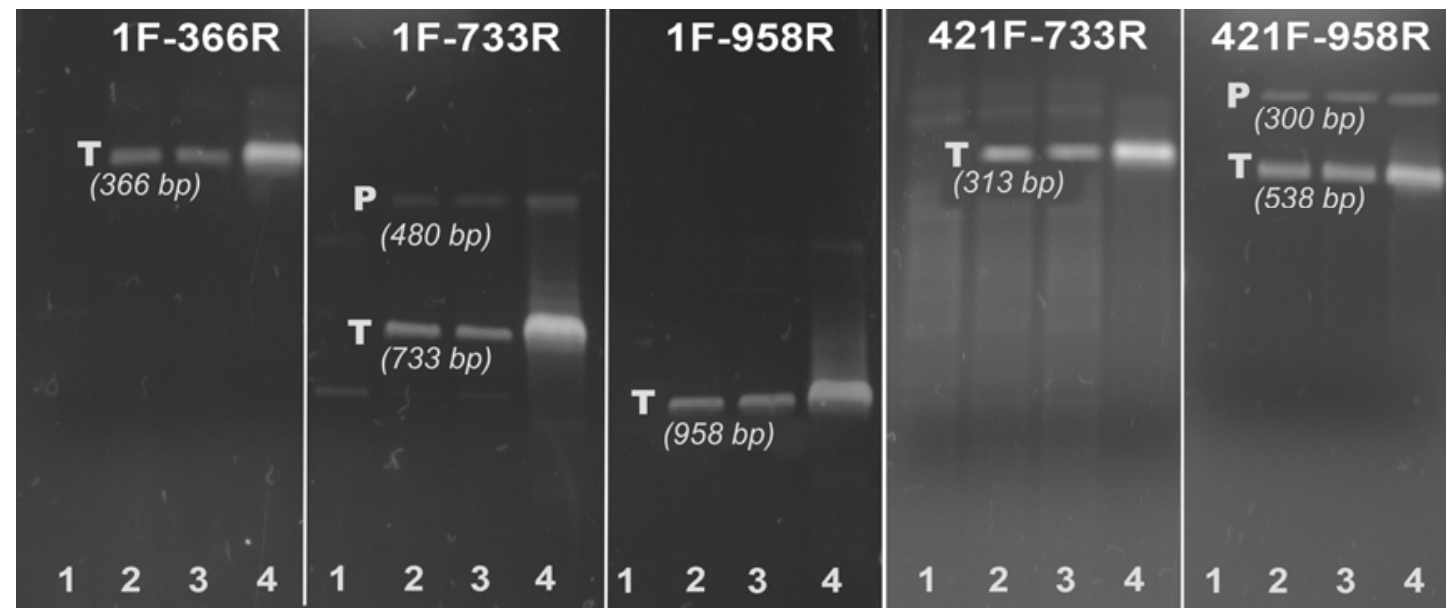

Fig 1. Identification of the rpgip1 transgene and plasmid sequences in $P$. sativum. 1 - Baroness - negative control, 2 - PGIP, 3 - PGIP+VST, 4 - pSCP1 plasmid. T - products corresponding to the transgene, $\mathrm{P}$ - products corresponding to other insert sequences.

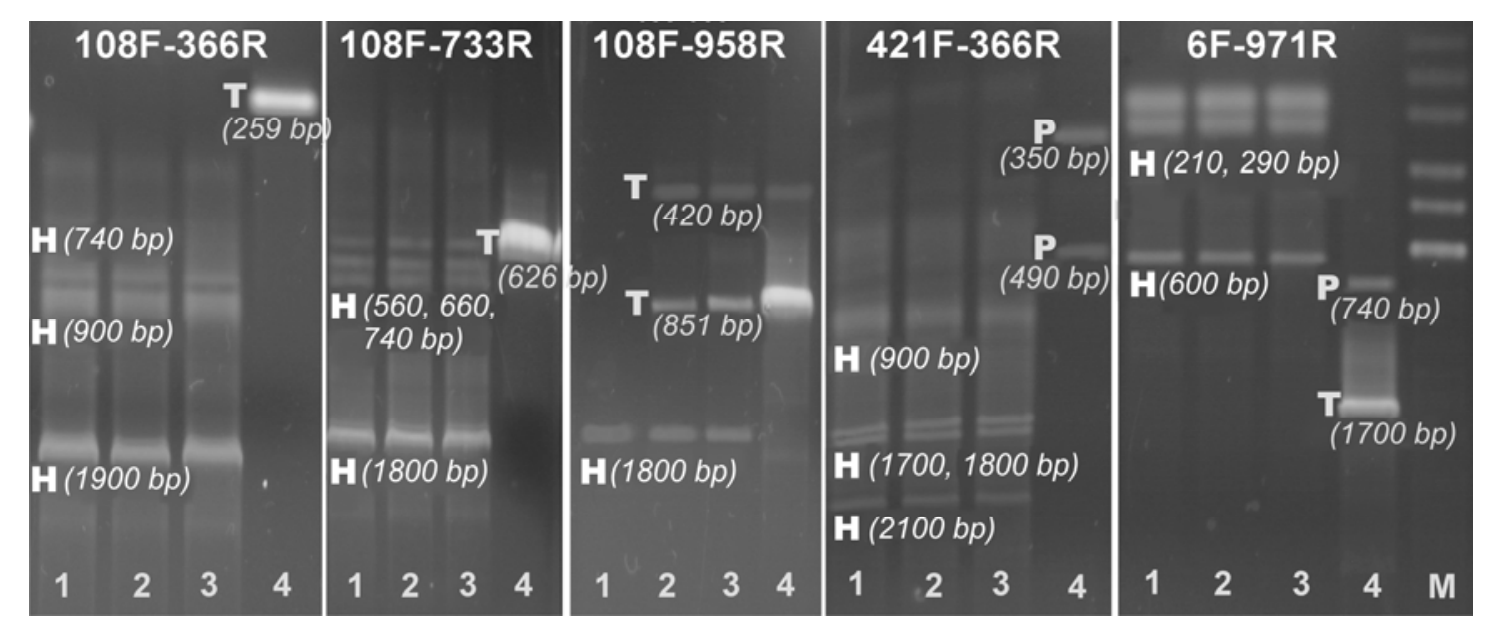

Fig 2. Unspecific amplification of $P$. sativum genomic DNA revealed by primers complementary to the rpgip1 transgene. 1 - Baroness - negative control, 2 - PGIP, 3 - PGIP+VST, 4 - pSCP1 plasmid. T - products corresponding to the transgene, $\mathrm{P}$ - products corresponding to other insert sequences, $\mathrm{H}-$ products corresponding to endogenous pea sequences homologous to the transgene (transposons or rpgip1 homologues), M - DNA marker. 
Table 2. Validation of primer combinations in identifying the rpgip1 transgene in P. sativum.

\begin{tabular}{|c|c|c|c|c|c|c|c|c|c|c|c|c|c|}
\hline \multirow[t]{2}{*}{$\begin{array}{l}\text { Primer } \\
\text { combination }\end{array}$} & \multirow{2}{*}{$\begin{array}{l}\text { Estimated } \\
\text { product } \\
\text { length } \\
\text { [bp] }\end{array}$} & \multicolumn{3}{|c|}{$\begin{array}{l}\text { Negative } \\
\text { controls }\end{array}$} & \multicolumn{2}{|c|}{$\begin{array}{l}\text { Transgenic } \\
\text { lines }\end{array}$} & \multicolumn{6}{|c|}{ rpgip1 hemizygotes } & \multirow{2}{*}{$\begin{array}{l}\text { Donor } \\
\text { species }\end{array}$} \\
\hline & & $\underset{\mathscr{E}}{\mathscr{E}}$ & 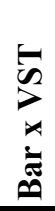 & 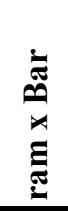 & $\hat{\theta}$ & $\begin{array}{l}5 \\
0 \\
+1 \\
0 \\
0 \\
0\end{array}$ & 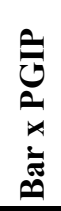 & $\begin{array}{l}\hat{0} \\
0 \\
\vdots \\
\vdots \\
\vdots \\
\vdots\end{array}$ & $\begin{array}{l}\Xi \\
\vdots \\
0 \\
0 \\
0 \\
0\end{array}$ & 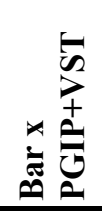 & 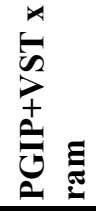 & 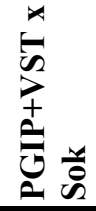 & \\
\hline \multicolumn{14}{|c|}{1 Primer pairs identifying the rpgip1 transgene or/and plasmid sequences } \\
\hline $1 F-366 R$ & 366 & 0 & 0 & 0 & $\mathrm{~T}$ & $\mathrm{~T}$ & $\mathrm{~T}$ & $\mathrm{~T}$ & $\mathrm{~T}$ & $\mathrm{~T}$ & $\mathrm{~T}$ & $\mathrm{~T}$ & 366 \\
\hline \multirow[t]{2}{*}{$1 F-733 R$} & 480 & 0 & 0 & 0 & $\mathrm{P}$ & $\mathrm{P}$ & 0 & 0 & $\mathrm{P}$ & $\mathrm{P}$ & $\mathrm{P}$ & $\mathrm{P}$ & \multirow[t]{2}{*}{1000} \\
\hline & 733 & 0 & 0 & 0 & $\mathrm{~T}$ & $\mathrm{~T}$ & $\mathrm{~T}$ & $\mathrm{~T}$ & $\mathrm{~T}$ & $\mathrm{~T}$ & $\mathrm{~T}$ & $\mathrm{~T}$ & \\
\hline 1F-958R & 958 & 0 & 0 & 0 & $\mathrm{~T}$ & $\mathrm{~T}$ & $\mathrm{~T}$ & $\mathrm{~T}$ & $\mathrm{~T}$ & $\mathrm{~T}$ & $\mathrm{~T}$ & $\mathrm{~T}$ & 1100 \\
\hline 421F-733R & 313 & 0 & 0 & 0 & $\mathrm{~T}$ & $\mathrm{~T}$ & $\mathrm{~T}$ & $\mathrm{~T}$ & $\mathrm{~T}$ & 0 & $\mathrm{~T}$ & $\mathrm{~T}$ & 450 \\
\hline \multirow[t]{2}{*}{ 421F-958R } & 300 & 0 & 0 & 0 & $\mathrm{P}$ & $\mathrm{P}$ & $\mathrm{P}$ & $\mathrm{P}$ & $\mathrm{P}$ & 0 & $\mathrm{P}$ & $\mathrm{P}$ & \multirow{2}{*}{$\begin{array}{l}538 \\
600\end{array}$} \\
\hline & 538 & 0 & 0 & 0 & $\mathrm{~T}$ & $\mathrm{~T}$ & $\mathrm{~T}$ & $\mathrm{~T}$ & $\mathrm{~T}$ & 0 & $\mathrm{~T}$ & $\mathrm{~T}$ & \\
\hline \multicolumn{14}{|c|}{2 Primer pairs revealed unintended amplification on pea homologous sequences } \\
\hline 108F-366R & $\begin{array}{l}740,900 \\
1900\end{array}$ & $\mathrm{H}$ & $\mathrm{H}$ & $\mathrm{H}$ & $\mathrm{H}$ & $\mathrm{H}$ & $\mathrm{H}$ & $\mathrm{H}$ & $\mathrm{H}$ & $\mathrm{H}$ & $\mathrm{H}$ & $\mathrm{H}$ & 0 \\
\hline $108 \mathrm{~F}-733 \mathrm{R}$ & $\begin{array}{l}560,660 \\
740,1800\end{array}$ & $\mathrm{H}$ & $\mathrm{H}$ & $\mathrm{H}$ & $\mathrm{H}$ & $\mathrm{H}$ & $\mathrm{H}$ & $\mathrm{H}$ & $\mathrm{H}$ & $\mathrm{H}$ & $\mathrm{H}$ & $\mathrm{H}$ & 500 \\
\hline \multirow[t]{3}{*}{ 108F-958R } & 420 & 0 & 0 & 0 & $\mathrm{~T}$ & $\mathrm{~T}$ & $\mathrm{~T}$ & $\mathrm{~T}$ & $\mathrm{~T}$ & $\mathrm{~T}$ & $\mathrm{~T}$ & $\mathrm{~T}$ & \multirow{3}{*}{$\begin{array}{l}1000 \\
1500\end{array}$} \\
\hline & 851 & 0 & 0 & 0 & $\mathrm{~T}$ & $\mathrm{~T}$ & $\mathrm{~T}$ & $\mathrm{~T}$ & $\mathrm{~T}$ & $\mathrm{~T}$ & $\mathrm{~T}$ & $\mathrm{~T}$ & \\
\hline & 1800 & $\mathrm{H}$ & $\mathrm{H}$ & $\mathrm{H}$ & $\mathrm{H}$ & $\mathrm{H}$ & $\mathrm{H}$ & $\mathrm{H}$ & $\mathrm{H}$ & $\mathrm{H}$ & $\mathrm{H}$ & $\mathrm{H}$ & \\
\hline 421F-366R & $\begin{array}{l}900,1700 \\
1800,2100\end{array}$ & $\mathrm{H}$ & $\mathrm{H}$ & $\mathrm{H}$ & $\mathrm{H}$ & $\mathrm{H}$ & $\mathrm{H}$ & $\mathrm{H}$ & $\mathrm{H}$ & $\mathrm{H}$ & $\mathrm{H}$ & $\mathrm{H}$ & $\begin{array}{l}1000, \\
1800, \\
2100\end{array}$ \\
\hline $6 \mathrm{~F}-971 \mathrm{R}$ & $\begin{array}{l}210,290 \\
600\end{array}$ & $\mathrm{H}$ & $\mathrm{H}$ & $\mathrm{H}$ & $\mathrm{H}$ & $\mathrm{H}$ & $\mathrm{H}$ & $\mathrm{H}$ & $\mathrm{H}$ & $\mathrm{H}$ & $\mathrm{H}$ & $\mathrm{H}$ & 580 \\
\hline \multicolumn{14}{|c|}{3 Multiplex PCR } \\
\hline Set1: & 366 & 0 & 0 & 0 & $\mathrm{~T}$ & $\mathrm{~T}$ & $\mathrm{~T}$ & $\mathrm{~T}$ & $\mathrm{~T}$ & $\mathrm{~T}$ & $\mathrm{~T}$ & $\mathrm{~T}$ & \multirow{4}{*}{$\begin{array}{l}366 \\
1000 \\
1100\end{array}$} \\
\hline $1 F, 366 \mathrm{R}$, & 480 & 0 & 0 & 0 & $\mathrm{P}$ & $\mathrm{P}$ & $P$ & $\mathrm{P}$ & $\mathrm{P}$ & $\mathrm{P}$ & $\mathrm{P}$ & $\mathrm{P}$ & \\
\hline $\begin{array}{l}733 R \\
958 F\end{array}$ & 733 & 0 & 0 & 0 & $\mathrm{~T}$ & $\mathrm{~T}$ & $\mathrm{~T}$ & $\mathrm{~T}$ & $\mathrm{~T}$ & $\mathrm{~T}$ & $\mathrm{~T}$ & $\mathrm{~T}$ & \\
\hline 501 & 958 & 0 & 0 & 0 & $\mathrm{~T}$ & $\mathrm{~T}$ & $\mathrm{~T}$ & $\mathrm{~T}$ & $\mathrm{~T}$ & $\mathrm{~T}$ & $\mathrm{~T}$ & $\mathrm{~T}$ & \\
\hline Set2: & 300 & 0 & 0 & 0 & $\mathrm{P}$ & $\mathrm{P}$ & $\mathrm{P}$ & $\mathrm{P}$ & $\mathrm{P}$ & 0 & 0 & 0 & \multirow{5}{*}{$\begin{array}{l}538, \\
1000 \\
1500\end{array}$} \\
\hline $108 \mathrm{~F}$, & 420 & 0 & 0 & 0 & $\mathrm{P}$ & $\mathrm{P}$ & $\mathrm{P}$ & $\mathrm{P}$ & $\mathrm{P}$ & 0 & 0 & 0 & \\
\hline $\begin{array}{l}421 \mathrm{~F}, \\
958 \mathrm{R}\end{array}$ & 538 & 0 & 0 & 0 & $\mathrm{~T}$ & $\mathrm{~T}$ & $\mathrm{~T}$ & $\mathrm{~T}$ & $\mathrm{~T}$ & 0 & $\mathrm{~T}$ & $\mathrm{~T}$ & \\
\hline 9J0ח & 851 & 0 & 0 & 0 & $\mathrm{~T}$ & $\mathrm{~T}$ & $\mathrm{~T}$ & $\mathrm{~T}$ & $\mathrm{~T}$ & $\mathrm{~T}$ & $\mathrm{~T}$ & $\mathrm{~T}$ & \\
\hline & 1800 & $\mathrm{H}$ & $\mathrm{H}$ & $\mathrm{H}$ & $\mathrm{H}$ & $\mathrm{H}$ & $\mathrm{H}$ & $\mathrm{H}$ & $\mathrm{H}$ & $\mathrm{H}$ & $\mathrm{H}$ & $\mathrm{H}$ & \\
\hline
\end{tabular}

0 - lack of amplification. $\mathrm{T}$ - products corresponding to the rpgip1 transgene, $\mathrm{P}$ - products corresponding to plasmid/insert sequences, $\mathrm{H}$ - products resulted from unintended amplification of homologous pea sequences, for $R$. idaeus, an approximate size of observed products is given. 
PCR amplification from pea genomic DNA using other five pairs of primers revealed completely different fingerprints than observed in the plasmid (Fig. 2). This second group comprised pairs: 108F-366R, 108F-733R, 108F-958R, 421F-366R and 6F-971R. Unexpected products were found both in transgenic and nontransgenic plants, hence providing an evidence for unspecific amplification from homologous sequences in pea genome (Table 2). All pairs but 108F-958R failed to detect either the transgene or other insert sequences. When PCR was performed with 108F-958R primers, the combination of a plasmid pattern and additional bands was noticed (Fig. 2). Hence, this pair may be in favour when a goal is to distinguish between the transgene and its endogenous homologues.

Based on the results for each pair of primers, two sets consisting of four (set 1: 1F, 366R, 733R, 958R) and three primers (set 2: 108F, 421F, 958R) were prepared with the aim of simultaneous amplification of different rpgip1 fragments. Fingerprints obtained from these two multiplex assays were sums of bands observed from individual pairs (Fig. 3) so the utility of using several primers at once was demonstrated. Alike individual pairs, the first set amplified only sequences of a transgenic origin (Table 2). The second one gave products of both transgene/insert and endogenous origins. Likely, this pattern was caused by the $108 \mathrm{~F}$ primer, combinations of which amplified mainly homologues. An additional advantage of multiplex PCR over singleplex is clear differentiation between the transgene and pgip genes present in the donor species, $R$. idaeus (Fig. 3). For example, bands revealed by $1 \mathrm{~F}-$ $366 \mathrm{R}$ and $421 \mathrm{~F}-958 \mathrm{R}$ pairs in red raspberry were indistinguishable from the rpgip1 amplicons in transgenic pea. Simultaneous amplification by $108 \mathrm{~F}$, $421 \mathrm{~F}$ and $958 \mathrm{R}$ (set 2) gave a three-band pattern in $R$. idaeus that was clearly distinct from the transgene fingerprint.

\subsection{Structure of the rpgip1 locus in transgenic plants}

The rpgip1 transgene authenticity was confirmed by sequencing six PCR products, each two from the PGIP, PGIP+VST lines and the pSCP1 plasmid. The sequences derived from 1F-733R primers had $678 \mathrm{bp}$ in transgenic plants and $691 \mathrm{bp}$ in the pSCP1. Expectedly, sequences obtained from $1 \mathrm{~F}-958 \mathrm{R}$ primers were longer and had $903 \mathrm{bp}$ and $889 \mathrm{bp}$, respectively. Irrespective of the template (plant or plasmid DNA), shorter and longer nucleotide sequences were identical on the length of ca. $690 \mathrm{bp}$, what confirmed that both primer pairs identified the rpgip1 transgene. This fact also enabled to use only longer sequences in further comparisons. Generally, significant rearrangements were not observed in the transgene (Fig. 4). However, all sequences were shorter than the original rpgip1 construct. They started from the $47 \mathrm{bp}$ position instead of $1 \mathrm{bp}$ despite the $1 \mathrm{~F}$ primer was used in sequencing reactions. The deletion of cytosine at 59 in relation to the rpgip1 template occurred in the PGIP+VST line and thymine was substituted by adenine at 392 in the PGIP line. In total 1806 unique base pairs were sequenced in two transgenic lines, so that the frequency of point mutations was $1.1 \times 10^{-3}$ or one mutation per 909 nucleotides.

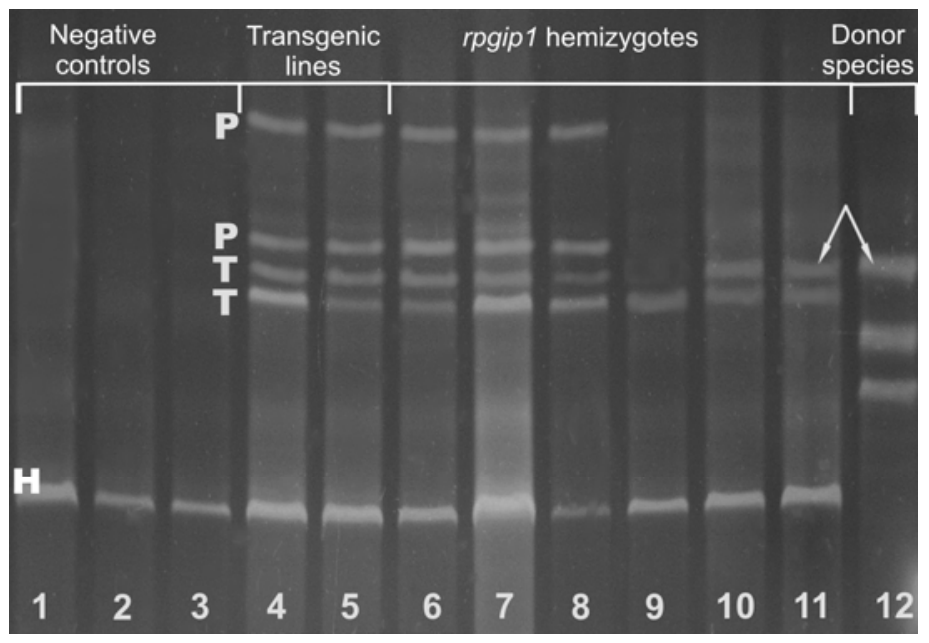

Fig. 3. Multiplex PCR profiles revealed by primers 108F, 421F and 958R (set 2). 1 - Baroness, 2 - Bar x Vst, 3 ram x Bar, 4 - PGIP, 5 - PGIP+VST, 6 - Bar x PGIP, 7 - arth x PGIP, 8 - PGIP x ram, 9 - Bar x PGIP+VST, 10 - PGIP+VST x ram, 11 - PGIP+VST x Sok, 12 - Rubus idaeus. T - products corresponding to the transgene, $\mathrm{P}$ - products corresponding to other insert sequences, $\mathrm{H}$ - products corresponding to endogenous pea sequences homologous to the transgene (transposons or rpgip1 homologues). Arrows indicate amplicons of transgenic and $R$. idaeus origin that have similar mobility. 


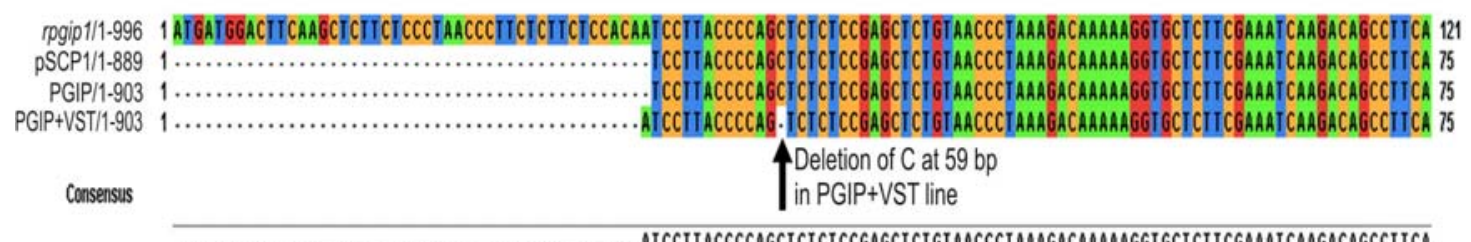

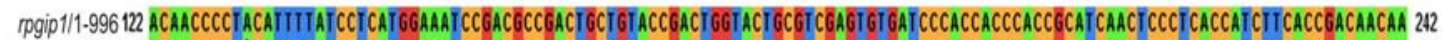

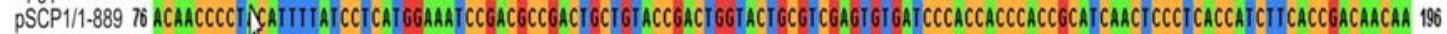

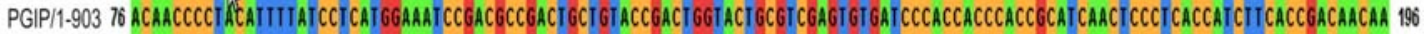
PGIP+VST/1-903 76 ACAACCCCIACAIIIIAICCICAIGgAaAICCGACGCCGACIGCIGTACCGACI GGTACIGCGICGAGTGIGAICCCACCACCCACCGCAICAACICCCICACCAICIICACCGACAACAA 190

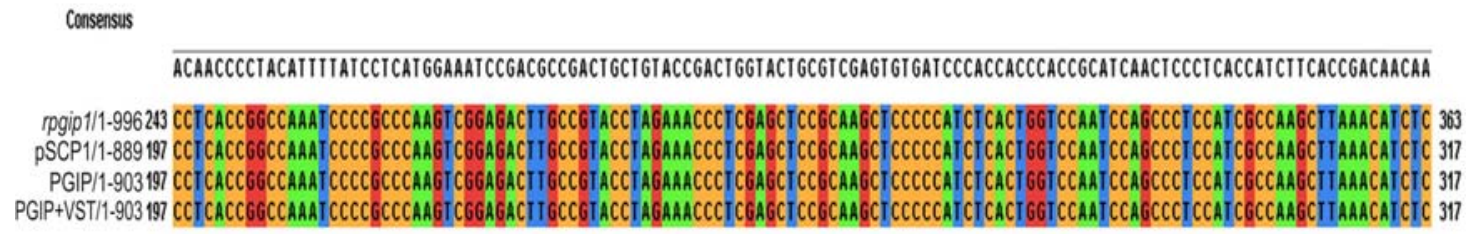

Consensus

CCICACCGGCCAAATCCCCGCCCAAGICGGAGACTIGCCGTACCTAGAAACCCTCGAGCICCGCAAGCTCCCCCATCTCACTGGTCCAATCCAGCCCTCCATCGCCAAGCTIAAACATCTC

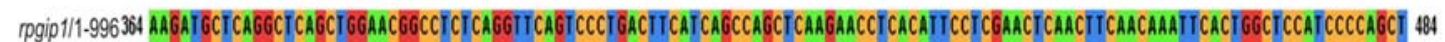

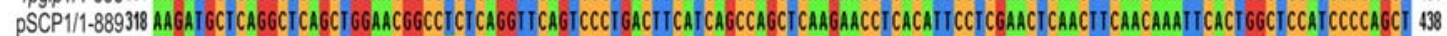

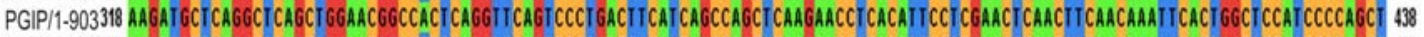

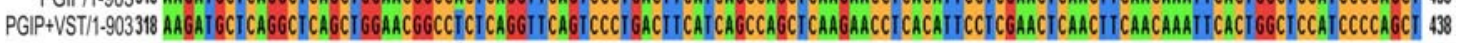

Consensus $\quad \uparrow_{\text {Substitution of T to A }} 392$ bp in PGIP line

AaGATGCTCAGGCTCAGCTGGAaCGGCCTCTCAGGTTCAGTCCCTGACTICATCAGCCAGCTCAAGAaCCTCACATTCCTCGAACTCAACTICAACAAATICACTGGCTCCATCCCCAGCT

Fig. 4. Alignment of the rpgip1 sequences obtained from the PCR product revealed by primers 1F-958R. rpgip1/1996 - a sequence used for transformation, pSCP1/1-889 - a sequence from the pSCP1 plasmid, PGIP/1-903 - a sequence from the PGIP line, PGIP+VST/1-903 - a sequence from the PGIP+VST line. Arrows indicate point mutations.

\subsection{Endogenous homologous sequences responsible for unintended amplification on pea genomic DNA}

To find out the nature of unintended amplification by several primer pairs, the site specificity of primers was checked by performing a sequence homology search through all known template sequences for Pisum sativum at NCBI. Four pairs that otherwise were effective in rpgip1 identification could also amplify other sequences from pea genome. Pairs 1F-733R, 1F958 could identify the Ogre retrotransposon (AY299397.1) while 421F-733R and 421F-958R demonstrated affinity to an unknown sequence (CU655881.1) and the Tfl gene responsible for late flowering (AY430579.1). Among primers unsuccessful in transgene identification, two pairs, 108F-733R and 108F-958R could identify the Psmar-2 - Mariner retrotransposon (AY833551.1).
Because the pgip genes are ubiquitous in plants, unintended amplification of endogenous homologues can not be excluded. Two putative pea homologues of rpgip1 were identified by NCBI searching, i.e., AB0877839 and AJ749705. Both sequences were derived from mRNA and they share of $65 \%$ and $60 \%$ of similarity to the rpgip1 transgene. Alignment of both sequences and the rpgip1 transgene at a protein level revealed several conserved regions between 164 and 331 amino acids corresponded to conserved residues at the nucleotide level. On the other hand, in silico PCR conducted on both pea homologues using all primer pairs complementary to rpgip 1 from $R$. idaeus produced none amplicons even though weak criteria were applied (4 - 7 mismatches allowed at the 3' end of primers).

\section{DISCUSSION}

The classical approach to GMO screening involves amplification of sequences common to many transgenic plants, such as the cauliflower mosaic virus $35 \mathrm{~S}$ promoter or the Agrobacterium tumefaciens nos terminator (Bonfini et al., 2001). Transgenic peas expressing rpgip1, like most GM plants, contain these 
sequences what enables to use numerous commercial kits for their routine screening. It should be stressed however, that the detection of common GMO markers only indicates that a sample contains DNA from any GM plant and provides neither trait nor transgene confirmation. An alternative is to focus on target sequences but then any PCR-based strategy depends on a transgene and organism. Besides the majority of studied primer pairs identified the rpgip1 transgene, some of them revealed additional bands corresponded to pea homologous sequences. Thus, the choice will depend very much on the objective of the PCR analysis. For routine screening purposes five pairs of primers (1F-366R, 1F-733R, 1F-958R, 421F-733R, 421F-958R) identifying unequivocally the rpgip1 transgene can be recommended to detect as many rpgip1 fragments as possible. If only a single pair is used, a small rearrangement within the transgene may prevent amplification and a GMO material may pass unnoticed. Notwithstanding several primer pairs can overcome this problem, the method is troublesome if many singleplex PCRs have to be used to test hundreds of samples as it is typical of food testing or GMO spread in the environment. Each pair needs a separate PCR reaction and sizing by agarose gel electrophoresis. Two proposed multiplex PCR assays allowing one-step identification of up to five GM-derived products provide promising simplification in detecting transgenic pea expressing antifungal genes. This procedure is in agreement with the current trends as emphasized by multiplex assays developed for the simultaneous detection of GM maize and soybean lines (Forte et al., 2005; Yoke-Kqueen et al., 2011). Rapidity and cost-efficiency are in favour of multiplex assays.

As more and more traits are introduced into plants, a challenge is how genetic variation of both donors and recipients influences the identification of GMOs. Risks rely on the false-positive results arising from wild ecotypes of a donor species. Primers 1F-366R gave a product of the same size in transgenic peas and wild raspberry. Similar fingerprints were observed for $421 \mathrm{~F}$ 958R primers. This means that samples containing raspberry products may be misidentified as GM pea derivatives. It is therefore necessary to employ multiprimers assays that often entail clearer differentiation as the present studies demonstrated. Surprisingly, such considerations have been scarce, presumably because the majority of so far marketed GM plants carry bacterial or viral genes that are avoided in detection procedures (Bonfini et al., 2001).

A major aspect of the rpgip1 detection in transgenic pea is the distinguishing between transgenes and endogenous homologues as shown for transgenic peas. This problem is rarely raised because most transgenic plants harbour insect or herbicide resistance genes that have not counterparts in plant genomes. Recently, genes from more or less related plant taxa are employed in plant transformation. A favourite example involves the wheat HMG gene, Dy10 encoding glutenin subunit and introduced into several wheat cultivars (Abdalla, 2007). But even more distant relationships do not prevent a transgene from interfering with endogenous homologues. The rpgip1 donor species, $R$. idaeus belongs to the Rosaceae family whereas the recipient, $P$. sativum is a member of Fabaceae. Nevertheless, five primer pairs amplified pea homologous sequences instead of the transgene. False-positive results originated from other genome homologues are critical in breeding transgenic crops. A common practice involves transformation of well responding genotypes and then, the transgene is introduced to other breeding lines by ordinary genetic crosses. Different allelic variants of homologues can have different affinity to primers designed on transgenes as well as a transgene may be rearranged during breeding. At this point, one can imagine employing one multiplex for preliminary analyses of the rpgip1 transgene structure (e.g., set 1) and another to reveal the rpgip1 transgene, insert sequences and homologues at once (e.g., set 2).

Important outcomes from the present studies is that some primers can identify homologues instead of the rpgip1 transgene. Expected patterns of the pSCP1 template in addition to primer specificity check and lack of unspecific products by in silico PCR enable to exclude the well-known points of consideration for unspecific amplification. What remains contentious is single-primer binding to the DNA template (Ma et al., 2011) However, each primer was used in different combinations and only some of them resulted in unspecific amplification. On the other hand, only sequences with few mismatches ( 1 or 2 ) at the 3 'end of primers can be used for effective PCR. A single mismatch at the last 10 bases can reduce the primer binding and can cause unintended amplification. Although positions of point mutations recognized at the rpgip1 transgene are apart from primer binding sites, they demonstrate such possibilities. Of course, the prerequisite for unspecific products is the presence of sequences complementary to rpgip1 primers in the pea genome. Otherwise, the amplification fails giving falsenegative results. For plant genomes, highly copied short or long direct repeats can become the target for nonspecific amplification. Indeed, four primers showed partial homology to pea retrotransposons. Just as transposons, endogenous pgips and especially their conserved regions are good templates for primers directed towards the transgene. Unexpectedly, in silico PCR on two known pea homologues did not confirm this thesis. This simulation inevitably entails the presence of so far unknown pgip genes in pea. Plants have evolved many PGIPs differing in inhibition 
profiles and recognition specificity to counterpart many PGs secreted by pathogens. Obviously, whether observed amplicons represent so far unknown pea pgips or other genomic sequences has to be clarified by sequencing and phylogenetic analyses.

One final point to consider is point mutations that may arise at transgenic loci through successive reproductive generations. Data from Arabidopsis thaliana (Papazova et al., 2008) and maize MON810 (La Paz et al., 2010) suggest the high stability of transgenes and flanking sequences from one side but from the other, an example of oat lines has demonstrated multiple transgene rearrangements, truncated sequences and complex transgene loci (Makarevitch et al., 2003). These contrary results can simply mean that transgene behaviour depends on a gene and organism. The rpgip1 transgene sequenced from the GM peas did not show any large rearrangements apart from a truncated fragment of $46 \mathrm{bp}$ at 5 'end. However, this may result from a sequencing procedure and explaining this lack needs further identification of transgene junctions. Noteworthy, two point mutations, one deletion and one substitution were recognized at the rpgip1 locus in transgenic peas. Likewise, 34 point mutations such as small deletions and base pair substitutions have occurred in the transgene coding region of Roundup Ready soybean transgenic plants during 10 years since their release (Ogasawara et al., 2005). In both cases the rate of mutations is comparable, $1.1 \times 10^{-3}$ at the rpgip1 transgene and $0.87 \times 10^{-3}$ at a transgene in soybean. Remarkably, the same research on Roundup Ready soybean has demonstrated similar mutation rates $(0.9 \mathrm{x}$ $10^{-3}$ ) at Cong gene, the host locus encoding conglycinin storage proteins. According to the neutral theory of molecular evolution, the frequency of mutations at the transgene should be comparable with that for host genes but whether or not this hypothesis is true for the rpgip1 transgene corroborates further comparisons.

To conclude, using several pairs of primers targeted towards different fragments of the rpgip1 transgene is an advantage over a single pair because at once they identify the transgene, distinguish between the transgene and endogenous homologues as well as enable to avoid false positive results due to contamination from donor species genes. Mutliplex assays provide further cost effective simplification of the procedure. Mutations at transgenic loci may complicate GMO identification but they do not seem to be more frequent than at host genes.

\section{ACKNOWLEDGEMENTS}

The research was supported by the European Union, the Marie Curie Host Fellowship for the Transfer of Knowledge programme under the project GenCrop,
MTKD-CT-2004-509834. We are grateful to Sylwia Ciaglo-Androsiuk for making crosses and isolating DNA from $\mathrm{F}_{1}$ plants.

\section{REFERENCES}

Abdalla, K.S. 2007. A simple and reliable PCR-based method for detection and screening of transgenic plants transformed with the same endogenous gene. Arabian Journal of Biotechnology 10: 155-160.

Bonfini, L., Heinze, P., Kay, S., Van den Eede, G. 2001. Review of GMO detection and quantification techniques. Ispra: European Commission, Joint Research Centre, pp. 67.

Cousin, R. 1997. Peas (Pisum sativum L.). Field Crops Research 53: 111-130.

Di Matteo, A., Bonivento, D., Tsernoglou, D., Federici, L., Cervone, F. 2006. Polygalacturonase-inhibiting protein (PGIP) in plant defence: a structural view. Phytochemistry 67: 528-533.

Eurostat, 2011. European Commission eurostat [Database on the Internet]. [cited 2011 August]. Available from http:// epp.eurostat.ec.europa.eu/portal/page/portal/eurostat/home/

Forte, V.T., di Pinto, A., Martino, C., Tantilo, G.M., Grasso, G., Schena, F.P. 2005. A general multiplex-PCR assay for the general detection of genetically modified soya and maize. Food Control 16: 535-539.

Janni, M., Sella, L., Favaron, F., Blechl, A.E., de Lorenzo, G., D'Ovidio, R. 2008. The expression of a bean PGIP in transgenic wheat confers increased resistance to the fungal pathogen Bipolaris sorokiniana. Molecular PlantMicrobe Interactions 21: 171-177.

La Paz, J.L., Pla, M., Papazova, N., Puigdomenech, P., Vicient, C.M. 2010. Stability of the MON 810 in maize. Plant Molecular Biology 74: 563-571.

Ma, J., Wang, P.W., Yao, D., Wang, Y.P., Yan, W., Guan, S.C. 2011. Single-primer PCR correction: a strategy for false-positive exclusion. Genetics and Molecular Research 10: 50-159.

Makarevitch, I., Svitashev, S.K., Somers, D.A. 2003. Complete sequence analysis of transgene loci from plants transformed via microprojectile bombardment. Plant Molecular Biology 52: 421-432. 
McDonald, G.K., Peck, D. 2009. Effects of crop rotation, residue retention and sowing time on the incidence and survival of Ascochyta blight and its effect on grain yield of field peas (Pisum sativum L.). Field Crops Research 111: 11-21.

Morino, K., Olsen, O.A., Shimamoto, K. 1999. Silencing of an aleurone-specific gene in transgenic rice caused by a rearranged transgene. The Plant Journal 17: 275-285.

Ogasawara, T., Chikagawa, Y., Arakawa, F., Nozaki, A., Itoh, Y., Sasaki, K., Umetsu, H., Watanabe, T., Akiyama, H., Maitani, T., Toyoda, M., Kamada, H., Goda, Y., Ozeki, Y. 2005. Frequency of mutations of the transgene, which might result in the loss of the glyphosate-tolerant phenotype, was lowered in Roundup Ready soybeans. Journal of Health Science 51: 197-201.

Papazova, N., Ghedira, R., van Glabeke, S., Bartegi, A., Windels, P., Taverniers, I., Roldan-Ruiz, I., van Bockstaele, E., Milcamps, A., van den Eede, G., Depicker, A., de Loose, M. 2008. Stability of the T-DNA flanking regions in transgenic Arabidopsis thaliana plants under influence of abiotic stress and cultivation practises. Plant Cell Reports 27: 749-757.

Polok, K. 2007. Molecular evolution of the genus Lolium L. Olsztyn: "SQL", 317 p. Available from http://www.uwm.edu.pl/katgenbiol

Powell, A.L., van Kan, J., ten Have, A., Visser, J., Greve, L.C., Bennet, A.B., Labavitch, J.M. 2000. Transgenic expression of pear PGIP in tomato limits fungal colonization. Molecular Plant-Microbe Interactions 13: 942-950.

Prioul-Gervais, S., Deniot, G., Receveur, E.M., Frankewitz, A., Fourmann, M., Rameau, C., Pilet-Nayel, M.L., Baranger, A. 2007. Candidate genes for quantitative resistance to Mycosphaerella pinodes in pea (Pisum sativum L.). Theoretical and Applied Genetics 114: 971984.
Richter, A., de Kathen, A., de Lorenzo, G., Briviba, K., Hain, R., Ramsay, G., Jacobsen, H.-J., Kiesecker, H. 2006. Transgenic peas (Pisum sativum) expressing polygalacturonase inhibiting protein from raspberry (Rubus idaeus) and stilbene synthase from grape (Vitis vinifera). Plant Cell Reports 25: 1166-1173.

Shanmugam, V. 2005. Role of extracytoplasmic leucine rich repeat proteins in plant defence mechanisms. Microbiological Research 160: 83-94.

Svitashev, S.K., Pawlowski, W.P., Makarevitch, I., Plank, D.W., Somers, D.A. 2002. Complex transgene locus structure implicates multiple mechanisms for plant transgene rearrangement. The Plant Journal 32: 433-445.

Szankowski, I., Briviba, K., Fleschhut, J., Schönherr, J., Jacobsen, H.-J., Kiesecker, H. 2003. Transformation of apple (Malus domestica Borkh.) with the stilbene synthase gene from grapevine (Vitis vinifera L.) and a PGIP gene from kiwi (Actinidia deliciosa). Plant Cell Reports 22: 141-149.

Timmerman-Vaughan, G.M., Frew, T.J., Russel, A.C., Khan, T., Butler, R., Gilpin, M., Murray, S., Falloon, K. 2002. QTL mapping of partial resistance to field epidemics of Ascochyta blight of pea. Crop Science 42: 2100-2111.

Yoke-Kqueen, C., Yee-Tyan, C., Siew-Ping, K., Son, R. 2011. Development of multiplex-PCR for genetically modified organism (GMO) detection targeting EPSPS and Cry $1 \mathrm{Ab}$ genes in soy and maize samples. International Food Research Journal 18: 515-522. 